\title{
THE CHALLENGES OF "IMPROVING" THE MODERN DEATH PENALTY
}

\author{
DOUGLAS A. BERMAN*
}

\section{INTRODUCTION}

In his dissent in McCleskey v. Kemp,${ }^{1}$ Justice William Brennan turned a famous phrase that has long resonated with criminal justice reformers. In upholding Georgia's capital sentencing system, the majority expressed concern about Eighth Amendment claims based on statistics revealing racial disparities in the application of the death penalty, fearing that such claims "would open the door to widespread challenges to all aspects of criminal sentencing." Justice Brennan lamented that "on its face, such a statement seems to suggest a fear of too much justice." 3

After watching and participating in various efforts to improve capital sentencing systems, I have concluded that almost everyone seriously involved in debates over the modern administration of death penalty actually has, and perhaps justifiably should have, a fear of too much capital justice. This essay seeks to explain this practical reality of modern death penalty advocacy in order to spotlight the problems it necessarily creates for any sustained efforts to improve the modern death penalty. By unpacking the fear of too much capital justice among capital punishment's active supporters and ardent opponents, this essay seeks first to expose an enduring disconnect between lay interest and insider advocacy concerning death penalty reform, and second to explain my pessimistic concern that even moderate and modest efforts to improve the modern administration of capital punishment may, more often than not, constitute something of a fool's errand.

Copyright (C) 2016 Douglas A. Berman.

* Robert J. Watkins/Procter \& Gamble Professor of Law, Moritz College of Law at The Ohio State University.

1. 481 U.S. 279 (1987).

2. Id. at $297-99$.

3. Id. at 339 (Brennan, J., dissenting). 
After discussing these dynamics surrounding modern capital punishment advocacy and reform, this essay closes by admitting uncertainty concerning what enduring lessons should be drawn from my observations for the future of the death penalty in the United States. It may be tempting to conclude simply that it would be far wiser for existing death penalty jurisdictions to try to end, rather than just mend, their modern capital punishment systems. But in an effort to provide a silver lining to what may otherwise seem like a dark story, this essay concludes by noting some unique potential benefits for American criminal justice systems when capital jurisdictions try (and fail) to achieve "too much justice" in their death penalty systems.

\section{WHY TOO MUCH CAPITAL JUSTICE IS NOT ONLY UNLIKELY BUT UNWANTED}

There are three critical practical and political realities surrounding the modern administration of capital punishment in the United States. First, a perfectly just death penalty system is practically impossible for fallible and politically-motivated Americans to create and maintain. Second, very few persons actively involved with or ardently concerned about modern death penalty systems are genuinely interested in making these systems ever more perfectly just. Third, most democraticallyelected lawmakers and their constituents are supportive of the death penalty because they generally believe ultimate crimes merit ultimate punishment and they are blissfully ignorant of the modern death penalty's smaller but ever important injustices and imperfections. These realities impact all legal and social debates over capital punishment, and collectively they persistently impede effective and efficient tinkering with most parts of the modern machinery of death.

Each of these realities could justify its own lengthy law review article. This part will briefly unpack them with an emphasis on how they impede efforts by individual jurisdictions, or the nation as a whole, to improve death penalty administration.

\section{A. Imperfect Justice}

Death penalty opponents often stress the reality and inevitability of human error as they contend even the smallest risks of wrongful executions justify the abolition of capital punishment. ${ }^{4}$ In the wake of

4. See, e.g., Daniel H. Benson et al., Executing the Innocent, 3 ALA. C.R. \& C.L. L. REV. 1 (2013); Michael L. Radelet, The Role of Innocence Argument in Contemporary Death Penalty 
many death row exonerations after the emergence of modern DNA technologies, this fallibility argument deeply resonates with many across all political and social demographics. Indeed, though there is limited evidence modern capital sentencing schemes have executed innocent persons and little reason to fear any factually innocent persons have been sentenced to death in recent years, concerns about wrongful death sentences persist and continue to propel death penalty repeal arguments in many jurisdictions. ${ }^{5}$

Human fallibility means that there will always be at least some risk of error-some risk of injustice - at every stage of decision-making in death penalty cases, from determining who should be condemned to die for their crimes to the review and carrying out of any death sentence. But the degree of due process afforded to capital defendants, the scope of appeals, and the selection of execution methods can and will greatly impact the magnitude of these risks of error. Hasty capital trials conducted amidst public outcry over horrific crimes with limited appellate review and followed swiftly by hangings conducted by untrained government officials - which was, of course, the norm for capital punishment administration throughout most of American history-will greatly enhance the risk of error in deciding who should die and in conducting executions. But thanks to legislative reforms of state death penalty statutes and procedures (especially after World War II) ${ }^{6}$ and to the Supreme Court's modern Eighth Amendment jurisprudence mandating special rules for and limitations on the application of the death penalty, ${ }^{7}$ the risk of egregious errors has been reduced considerably in

Debates, 41 TEX. TECH. L. REV. 199 (2008) ("A central component of the death penalty abolitionists" argument from the last 250 years has been the problem of erroneous convictions.").

5. As a matter of basic political philosophy, I must note that I have always found the fallibility argument for abolishing the death penalty to be somewhat inconsistent with how we generally assess other government functions. The known and unavoidable risk of human error that might result in victimizing some innocent persons does not generally keep governments from engaging in life-and-death activities - activities ranging from waging war to regulating drug safety to running a public transit system - if the public and lawmakers view the benefits of these government activities to be worth the risks. Of course, governments can and will seek to reduce risks of human error as much as possible, but nobody argues that city buses should forever stop running because there is an ever-present risk that a negligent bus driver might cause a fatal crash.

6. See generally Douglas A. Berman, Foreword: Addressing Capital Punishment Through Statutory Reform, 63 OHIO ST. L.J. 1, 1-2 (2002).

7. See Kennedy v. Louisiana, 554 U.S. 407 (2008); Atkins v. Virginia, 536 U.S. 304 (2002); Sumner v. Shuman, 483 U.S. 66 (1987); Tison v. Arizona, 481 U.S. 137 (1987) Eddings v. Oklahoma, 455 U.S. 104 (1982); see also Rachel E. Barkow, The Court of Life and Death: The Two Tracks of Constitutional Sentencing Law and the Case for Uniformity, 107 MICH. L. REV. 1145, 1150 (2009) (detailing that Supreme Court "has recognized a series of constitutional rights that apply only to capital defendants [which provide them with] greater procedural and substantive 
modern times when selecting who should be condemned to die and in carrying out executions.

But of course, as other articles in this issue document, ${ }^{8}$ even though death penalty administration is far less fraught with risks of error and injustice now than generations ago, few observers of the modern administration of the death penalty systems would vigorously dispute Professor James Liebman's assertion that the "capital punishment system in the United States is [still] broken." Whether evidenced by the American Bar Association's findings of "serious problems ... in every state death penalty system" it studied, ${ }^{10}$ or other empirical and anecdotal evidence that the administration of the death penalty is not significantly more reliable, accurate, or fair today than in prior eras, ${ }^{11}$ nearly all serious observers recognize that the modern administration of capital punishment remains flawed in various ways. Persistent concerns with death penalty administration include racial disparities and other inequities in who is sentenced to death, underfunding and poor quality of representation many capital defendants receive, the often arcane procedural complications in reviewing capital cases, and extended delays between imposing and carrying out duly imposed death sentences. $^{12}$

Though there are many accounts of, and varied allocations of blame for, the sorry state of capital punishment, it seems fair to attribute many enduring problems with the administration of the death penalty to the

protections" than noncapital defendants).

8. See, e.g., Frank W. Baumgartner, The Geographic Distribution of US Executions, 11 DUKE J. OF CONST. L \& PUB. POL'Y 1 (2016); John H. Blume \& Lindsey S. Vann, Forty Years of Death: The Past, Present, and Future of the Death Penalty in South Carolina; 11 DUKE J. OF COnst. L \& PUB. POL'Y 183 (2016); John Donohue, Empirical Analysis and the Fate of Capital Punishment, 11 DUKE J. OF CONST. L \& PUB. POL'Y 51 (2016).

9. James S. Liebman, Opting for Real Death Penalty Reform, 63 OHIO ST. L.J. 315 (2002). Professor Liebman first used the term "broken" to describe the modern death penalty system in his examination of reversal rates in death penalty cases. See James S. Liebman et al., A Broken System: Error Rates in Capital Cases, $1973-1995$ (2000), http://www2.law.columbia.edu/instructionalservices/liebman/.

10. American Bar Association, Death Penalty Moratorium Implementation Project, State Death Penalty Assessments: Key Findings (Sept. 2007), http://www.abanet.org/moratorium/ assessmentproject/keyfindings.doc.

11. See, e.g., John D. Bessler, Tinkering Around the Edges: The Supreme Court's Death Penalty Jurisprudence, 49 AM. CRIM. L. REV. 1913, 1941 (2012) (lamenting that "despite all the efforts by legislators and the courts, ... the death penalty remains as arbitrary and as problematic as ever").

12. Justice Stephen Breyer has provided perhaps the most comprehensive recent accounting of defects in the modern administration of the death penalty in his opinion urging the Supreme Court to "reopen the question" of "whether the death penalty violates the Constitution." See Glossip v. Gross, 135 S. Ct. 2726, 2755-56 (2015) (Breyer, J., dissenting). 
reality that a perfectly just death penalty system is practically impossible for fallible Americans to create and maintain. Within a politicallysensitive legal system with public opinion still running strongly in favor of capital punishment, ${ }^{13}$ police, prosecutors, lawmakers, and judges continue to feel politically compelled to demonstrate and vindicate a commitment to a functioning death penalty system. With political pressures to subject at least some murderers to the ultimate punishment, state officials are often content, at least subconsciously, with a capital punishment system that is merely, as the saying goes, "good enough for government work." In turn, as enduring problems appear endemic to modern death penalty systems, we must confront the realities that lead precious few capital punishment insiders and advocates to be genuinely interested in more perfect capital justice.

\section{B. Disinterest in a More Perfect Capital Justice}

For nearly all death row defendants, their lawyers, and opponents of capital punishment, the only perfect death penalty system is one that has been abolished. Unsurprisingly, as death penalty opponents regularly chronicle flaws in capital punishment's administration, rarely do they seriously advocate realistic legislative reforms that could enable modern death penalty systems to operate more effectively and efficiently. Death penalty opponents regularly spotlight tales of wrongful convictions and botched executions primarily to boost their advocacy for the elimination of capital punishment altogether. When lamenting racial or geographic or social disparities in the application of death sentences or in patterns of execution, death penalty opponents devote precious little attention to how increasing the number of death sentences or executions in a particular jurisdiction could help make the system more equitable and consistent. ${ }^{14}$ Complaints from abolitionists about the modern death penalty being "unreliable," "arbitrary," or involving "excessive delays" come with calls to eliminate the death penalty entirely rather than with any suggestions or concrete proposals concerning how to make death sentences more reliable, less arbitrary and less

13. See Andrew Dugan, Gallup, Solid Majority Continue to Support Death Penalty (Oct. 15, 2015), http://www.gallup.com/poll/186218/solid-majority-continue-support-death-penalty.aspx (reporting that more than "six in 10 Americans favor the use of the death penalty for a person convicted of murder").

14. For example, if capital disparity concerns are focused on evidence that African-Americans or murderers from a particular county are far more likely to sentenced to death than others for similar murders, sentencing more Caucasians or murderers from other counties to death would potentially address disparity concerns by making a capital punishment system operate in a more equitable and consistent manner. 
subject to delay. Moreover, in the occasional case in which the death penalty seems to be operating without being unduly infected by the usual systemic problems - such as the recent federal capital prosecution of Dzhokhar Tzarnaev, who was sentenced to die for the 2014 Boston Marathon terrorist bombing-death penalty opponents are quick to assert the case is unrepresentative of modern capital punishment systems rather than to encourage giving attention to the case as a model of improved capital justice to seek to replicate in the future. ${ }^{15}$

As a matter of basic philosophy and political practicalities, it is hardly surprising that death penalty opponents would generally resist and fear improved capital justice. First, most opponents of the death penalty believe as a matter of principle that state killing as a form of punishment is inherently unjust and always unjustifiable. ${ }^{16}$ Consequently, for persons categorically opposed to capital punishment in any and all cases, to even talk about improving capital justice is problematically tantamount to admitting that justice is possible and should be pursued in and through capital prosecutions. Second, as a matter of political practicalities, sophisticated opponents of the death penalty realize that any death penalty system made truly more effective and justthat is, a system which significantly minimized the risks of errors and injustice-necessarily becomes a death penalty system that is far more likely to garner broad public support and to increase the number of persons sentenced to death and ultimately executed. ${ }^{17}$

For nearly all capital prosecutors and ardent supporters of the death penalty, their philosophical views and modern practicalities run forcefully in the opposite direction. For capital insiders and advocates, existing death penalty systems are already, in a sense, "too perfect" because they too readily enable too many intentional murderers and their

15. See generally Austin Sarat, Will Tsarnaev's Death Sentence be America's Last?, POLITICO MAGAZINE (May 15, 2015), http://www.politico.com/magazine/story/2015/05/tsarnaev-death-sentence-americas-last-death-penalty-on-decline-118005.

16. See, e.g., Amnesty International, End Capital Punishment, at http://www.amnestyusa.org/our-work/campaigns/abolish-the-death-penalty ("The death penalty is the ultimate, irreversible denial of human rights.”); Editorial, An Indefensible Punishment: The Death Penalty, Unjust and Arbitrary, Cannot Be Made To Conform to the Constitution, N.Y. TIMES, Sept. 26, 2011, at A28.

17. A leading commentary authored two decades ago discussing the impact of the Supreme Court's Eighth Amendment jurisprudence recognized that, by reducing the most ugly application of the death penalty, the Court ultimately made the practice of capital punishment more entrenched. See Carol S. Steiker \& Jordan M. Steiker, Sober Second Thoughts: Reflections on Two Decades of Constitutional Regulation of Capital Punishment, 109 HARV. L. REV. 355 (1995) (reviewing critically the Supreme Court's "complex, arcane, and minutely detailed" constitutional death penalty jurisprudence). 
defenders to delay or avoid the ultimate punishment for ultimate crimes. ${ }^{18}$ With only a tiny fraction of serious murderers actually subject to capital charges and often decades elapsing between a capital sentence and even the setting of an execution date, proponents of capital punishment are generally far more concerned about too many murderers avoiding justice via "legal tricks" to dodge the imposition of a death sentence or to persistently delay any execution date. The occasional anecdote of a wrongful conviction or botched execution of a murderer does not trouble death penalty proponents nearly as much as what they consider to be regular and repeated stories of horrific criminals avoiding capital prosecution altogether or delaying an execution for decades. Moreover, sophisticated proponents of capital punishment realize that serious efforts to further "perfect" existing death penalty systems will provide defense lawyers and abolitionists with still more opportunities to impede the prospects and progress of even the most horrific murderer advancing toward a state's death chamber. ${ }^{19}$

Some modern capital punishment reform stories provide ample evidence that few advocates are genuinely interested in making the administration of capital punishment more perfect. A decade ago, for example, then-Massachusetts Governor Mitt Romney created a blue-ribbon panel of experts to devise a death penalty system for his state to be "as narrow and as foolproof as humanly possible." ${ }^{20}$ Consistent with its charge, the Governor's Council on Capital Punishment produced an impressive report with "ten proposals-many of which are unprecedented in the history of American capital punishment - that, if adopted in their entirety, can allow creation of a fair capital punishment statute for Massachusetts that is as narrowly tailored, and as infallible, as humanly possible." ${ }^{21}$ But, tellingly, the Council's proposals and the draft legislation then-Governor Romney submitted to enact a more perfect system of capital justice received virtually no support in Massachusetts:

18. See, e.g., Kent Scheidegger, Rebutting The Myths About Race and the Death Penalty, 10 OHIO ST. J. CRIM. L. 147, 164-65 (2012) (expressing concerns about the potential costs of "insufficient application" of the death penalty).

19. See, e.g., Joe Deters, Ron O'Brien \& Stephen Schumaker, Dissenting Report From Members Of The Joint Task Force To Review The Administration Of Ohio's Death Penalty 45 (2014), http://www.sc.ohio.gov/Boards/deathPenalty/resources/dissentingReport.pdf.

20. Letter from Mitt Romney, Governor of Massachusetts, to Members of the Senate and House of Representatives of the Commonwealth of Massachusetts (Apr. 28, 2005), http://www.nodp.org/ma/death_penalty_4-28-5.pdf.

21. Governor's Council on Capital Punishment, Final Report 3 (2004), http://www.mass.gov/courts/docs/lawlib/docs/5-3-04governorsreportcapitalpunishment.pdf. 
both death penalty proponents and opponents attacked the draft legislation on numerous grounds. ${ }^{22}$ Moreover, the astute procedural and substantive reforms suggested by Governor Romney's blue-ribbon panel-like those of many other groups urging improvements to the administration of the death penalty ${ }^{23}$ - have found few serious advocates and have had virtually no traction in modern legislative debates in those jurisdictions still in the business of state killing. ${ }^{24}$

The pragmatic disinterest among insiders for too much capital justice also largely accounts for why states have often sought to keep secret information related to the acquisition of lethal injection drugs and execution procedures, rather than seriously exploring improved execution methods. ${ }^{25}$ State officials believe, justifiably, that any informationsharing good deed will be punished through new rounds of litigation brought by death row defendants and death penalty opponents. ${ }^{26}$ And state officials believe, reasonably, that most everyone complaining about lethal injection protocols will not start endorsing capital punishment if and when the state successfully develops a more perfect execution method. State officials also believe, explained below, that relatively few persons other than ardent death penalty opponents are genuinely all that concerned about smaller injustices in the administration of the

22. See David S. Bernstein, The Sudden Death of Romney's Dream: What Once Seemed Like a Clever Ploy Has Become a Political and Policy Disaster for the Governor, THE BOSTON PHOENIX (July 22, 2005), http://www.bostonphoenix.com/boston/news_features/other_stories/multi-page/documents/04838552.asp; see also Russell G. Murphy, Execution Watch: Mitt Romney's "Foolproof” Death Penalty Act and the Politics of Capital Punishment, 45 SUFFOLK U. L. REV. 1, 16-24 (2011) (detailing the widespread negative reactions and criticisms of the Governor's Council Report and subsequent legislation).

23. See, e.g., The Constitution Project, Mandatory Justice: Eighteen Reforms to the Death Penalty (2001); AM. BAR Ass'N., Death Penalty Due Process Review Project, The State of the Modern Death Penalty in America (2013), http://www.americanbar.org/content/dam/aba/ administrative/ death_penalty_moratorium/aba_state_of_modern_death_penalty_web_file.authcheckdam.pdf.

24. See Murphy, supra note 22, at 16 (noting how little commentary there has been on Governor Romney's death penalty reform efforts and his expert panel's report and recommendations even though they "represented an ambitious attempt to deal with some of the major problems with capital prosecutions in this country").

25. See Michael Rooney, Lethal Secrecy: State Secrecy Statutes Keep Execution Information From The Public, THE News Media AND THE LAW 2 (2014).

26. Importantly, I do not question either the judgment or ethics of defense lawyers aggressive challenging lethal injection protocols or any other execution method adopted by a state; indeed, when I have defended persons on death row, I felt a professional obligation to raise any and every non-frivolous argument that might delay or prevent my client's execution. But the fact that defense attorneys have an ethical responsibility to try to delay or prevent executions contributes to the "bunker mentality" that state officials adopt in response to evidence about flaws in their lethal injection protocols or other aspects of their capital punishment systems. 
death penalty when this punishment is applied to the worst (indisputably guilty) murderers.

\section{Ignorance Is Bliss}

For the vast majority of the public and lawmakers, the death penalty is a highly symbolic and largely inconsequential aspect of governmental work. Even in the few remaining active death penalty states like Texas and Florida, capital cases are a tiny component of massive criminal justice systems and an even more miniscule part of state governments' broader activities. Practically speaking, the average citizen is impacted far more by street cleaning schedules and school lunch menus than by the day-to-day administration of the death penalty. Moreover, the average citizen assumes-correctly and justifiably in my opinion - that most prosecutors and judges generally aspire to reduce the most extreme risks of error in the operation of the death penalty. Politically speaking, the average lawmaker recognizes that voters will care about her basic position on the death penalty, but she also realizes that the symbolism of her position is far more important than any specifics.

These practical and political realities mean that the vast majority of lawmakers and members of the public are blissfully ignorant concerning all the modern death penalty's smaller injustices and imperfections. ${ }^{27}$ The one exception that proves the rule here is public and political concern for wrongful convictions. As evidenced by all the media attention given to wrongful convictions, the public clearly is troubled to discover a factually innocent person has been sentenced to death. However, once assured of a condemned person's guilt, any and all other asserted problems with a death sentence pale in comparison. ${ }^{28}$ Only the most engaged activists can keep up with the copious research about the modern operation of the death penalty, and often lawmakers will resist efforts to commission official studies of the costs and consequences of death penalty's administration absent evidence to suggest numerous innocent persons have been wrongly convicted and sentenced to death. ${ }^{29}$ Of course, the general public and lawmakers do not wish to embrace or advocate for a deeply flawed death penalty system, and

27. Stephen F. Smith, The Supreme Court and the Politics of Death, 94 VA. L. REV. 283 (2008).

28. See David R. Dow, Death by Good Intentions, WASH. Post, Oct. 15, 2006, at B07 (explaining why a "focus on innocence has insidiously distracted" from other problems endemic to capital punishment systems).

29. See, e.g., JoAnne Young, Nebraska Lawmakers Turn down Death Penalty Study, LinCOLN J. STAR, Mar. 25, 2010, at A1. 
thus concrete evidence of wrongful convictions or badly botched executions will often prompt executive officials and legislators to begin a serious program of study and reform. But when identified problems can be viewed as just administrative imperfections rather than grotesque injustices, most people remain more interested in the death penalty as an idea than as a practice. Indeed, by paying little attention to the death penalty in practice, the general public and its elected representatives can hold onto the blissfully ignorant belief that our existing death penalty systems at least aspire to be as perfect as possible.

\section{THE IMPACT AND IMPORT OF FEARING "TOO MUCH CAPITAL JUSTICE"}

The practical reality of modern death penalty advocates fearing too much capital justice necessarily creates considerable difficulties for any concerted efforts to engineer genuine improvements to the operation of modern death penalty systems. I noted briefly in Part I above the ugly history (and still unexplored proposals) that followed after thenMassachusetts Governor Mitt Romney tried to create an ideal capital punishment system for his state a decade ago ${ }^{30}$ Similar stories concerning expert panels proposing reforms and confronting political and practical roadblocks can be recounted with varied particulars in various existing capital jurisdictions ranging from California ${ }^{31}$ to Illinois $^{32}$ to North Carolina ${ }^{33}$ to Tennessee. ${ }^{34}$ In order to provide more details on a recent version of this story, and especially to provide an important silver lining to conclude an otherwise dark law reform story, let me relay a version of this tale as it has played out recently in the bellwether state of Ohio.

30. See supra notes 20-24 and accompanying text.

31. Sarah Rose Weinmand, The Potential and Limits of Death Penalty Commissions as Tools For Reform: Applying Lessons from Illinois and New Jersey to Understand the California Experience, 14 BERKELEY J. CRIM. L. 303 (2009).

32. Thomas P. Sullivan, Proposed Reforms to the Illinois Capital Punishment System: A Status Report, 96 ILL. B.J. 38 (2008); George Ryan, Moratorium on Death Row Executions, 5 LoY. J. PUB. INT. L. 1 (2003).

33. Robert P. Mosteller, Responding to McCleskey and Batson: The North Carolina Racial Justice Act Confronts Racial Peremptory Challenges in Death Cases, 10 OHIO ST. J. CRIM. L. 103 (2012).

34. William Redick, Is Tennessee Going to Fix Its Death Penalty?: The 2007-2008 Legislative Death Penalty Study Committee, TENN. BAR J. 12 (2009). 


\section{A. The Dark Clouds of Ohio's Recent Capital Reform Efforts}

I personally observed the practical reality of modern death penalty advocates fearing too much capital justice in recent years while serving as a member of the Joint Task Force to Review the Administration of Ohio's Death Penalty. This Task Force, which Ohio's Chief Justice Maureen O'Connor created in Fall 2011 as a cooperative effort between the Supreme Court of Ohio and the Ohio State Bar Association, was tasked with conducting a thorough review of the state's capital punishment system. ${ }^{35}$ Chief Justice O'Connor was quick to stress that the Task Force was "not being asked to make a judgment on whether Ohio should or should not have the death penalty," but rather would study how to improve the state's existing laws and procedures to ensure that Ohio's death penalty is administered in "the most fair and judicious manner possible." ${ }^{36}$ This Task Force, chaired by a retired appellate judge with members including judges, prominent capital prosecuting and defense attorneys, elected lawmakers, and law professors, was thus tasked to do what I have suggested ardent advocates are disinclined to do: figure out how the state of Ohio could achieve more perfect capital justice through concrete recommendations for legal reform.

Disconcertingly, and as a sign of future controversies, this Task Force struggled at the outset with the question of whether it should begin and base its work on the 2007 report of the American Bar Association's Death Penalty Assessment Project, which was highly critical of many aspects of Ohio's capital punishment laws and practices. ${ }^{37}$ Prosecutors on the Task Force complained that this report was sponsored by an organization that had been long advocating for a moratorium on all executions and had produced its Ohio report without the input of any active prosecutors. As foreshadowed by this initial controversy and at all times thereafter, Ohio prosecutors seemed suspicious of much of the Task Force's work and seemed begrudging participants, at best. As effectively documented in a recent article by Professor Margery Koosed, throughout Task Force meetings and an elaborate subcommittee review process, "prosecutorial participation was uneven":

35. See The Supreme Court of Ohio \& Ohio Judicial System, Death Penalty Task FORCE RECEIVES CHARGE (Nov. 3, 2011), http://www.supremecourt.ohio.gov/PIO/news/2011/deathPenaltyTF_110311.asp.

36. Id.

37. See Am Bar. Ass'n., Evaluating Fairness and Accuracy in State Death Penalty Systems: The OHio DeAth Penalty Assessment Report (2007), http://www.americanbar.org/content/dam/aba/migrated/moratorium/assessmentproject/ohio/finalreport.authcheckdam.pdf. 
prosecutors appeared only seriously engaged in the Task Force's work "when submitt[ing] a number of proposals that would make it easier to obtain death sentences," and it was later revealed "that some prosecutors agreed to join the Joint Task Force only when they were promised a minority or dissenting report would be possible. ${ }^{\prime 38}$

To its credit and despite a fair amount of internal and external controversy, the Task Force soldiered on despite frequent prosecutorial push-back; nearly all other Task Force members engaged in considerable work over nearly three years of meetings and research to submit to the Chief Justice in April 2014 the "Final Report \& Recommendations of The Joint Task Force To Review the Administration of Ohio's Death Penalty," ${ }^{39}$ recommending fifty-six modifications to the administration of capital punishment in Ohio. ${ }^{40}$ Among its recommendations, the report included some relatively modest suggestions calling for the adoption of existing best practices from other capital jurisdictions, for example (1) requiring that custodial interrogations in potential capital cases be video/audio recorded; (2) having crime labs working on capital case evidence be certified by a recognized agency; and (3) raising the necessary qualifications for lawyers representing defendants facing the death penalty. ${ }^{41}$ In addition, the Task Force report also included a few bolder recommendations that could limit the applicability of the death penalty, for example (1) excluding from eligibility for the death penalty defendants who suffer from "serious mental illness;" (2) providing that a death sentence cannot be considered or imposed absent compelling direct evidence of guilt; and (3) creating a death penalty charging committee at the Ohio Attorney General's Office to be made up of former county prosecutors, appointed by the Governor, and members of the Ohio Attorney General's staff. ${ }^{42}$

38. Margery M. Koosed, Trying to Get It Right-Ohio, From the Eighties to the Teens, 43 HOFSTRA L. REV. 783, 819-821 (2015).

39. The Supreme COURT OF OHIO \& OHIO JUdiCIAl SYSTEM, JOINT TASK ForCE TO REView THE Administration OF OHio's DEATH PENAlty, Final Report \& RECOMMENDATIONS (Apr. 2014), http://www.sc.ohio.gov/Boards/deathPenalty/resources/finalReport.pdf.

40. See Chris Davey, Death Penalty Task Force Releases Final Report, CT. NEws OHIO (May 21, 2014), http://www.courtnewsohio.gov/happening/2014/deathPenaltyTFReport_052114.asp\#.VwGV1eIrLIU.

41. See id. Recommendation Nos. 1, 3, 13-14.

42. See id. Recommendation Nos. 8-9, 17-18, 34. 
But in a telling response to the Task Force's efforts and work-product, the prosecutors involved in the Task Force's work produced a minority report concluding that many of the recommendations "would establish a series of procedural and legislative nightmares." ${ }^{43}$ In the view of capital prosecutors, some of the Task Force's "recommendations would tie the death-penalty system up in knots, creating procedural and litigative traffic jams that would potentially tie up particular cases in litigation even more than is already occurring." ${ }^{44}$ Most importantly, the prosecutors stated that although the Task Force was not created to advise on the existence of the death penalty:

In several of its recommendations, however, the Task Force veered off its narrow mandate and is making recommendations that are anti-death penalty. The work of the Task Force was strongly influenced by a pro-defense majority bent on an agenda of abolition, not fairness....

In sum, a committee majority, operating under the openly conceded purpose of implementing the 2007 proposals of the American Bar Association's anti-death penalty promoratorium "Ohio Team," has produced just what anyone would expect. A large number of the recommendations would establish a series of procedural and legislative nightmares that would render Ohio's death penalty inoperable. This, of course, is a result the Death Penalty Task Force was not even permitted to consider. Sadly, these recommendations have little to do with "fairness," the stated goal of the Task Force. ${ }^{45}$

In other words, in the view of the insider capital punishment supporters in Ohio, a "pro-defense majority bent on an agenda of abolition" controlled an expert group tasked with looking for ways to improve the state's capital punishment system. As a participant on the Task Force who has never been "bent on an agenda of abolition," I am eager to assert that this dissenting report's accusations about the Task Force's work were more bombastic than justified. At the same time, again drawing on my perspective as a participant on the Task Force, I can understand how various comments and proposals made throughout the process led the authors of the dissenting report to conclude that a number of recommendations were inspired by anti-death penalty sentiments. In short, the "fear of too much capital justice" seemed everpresent in the efforts and reactions to the efforts of this Task Force to improve capital justice.

43. Joe Deters, Ron O'Brien \& Stephen Schumaker, Dissenting Report From Members Of The Joint Task Force To Review The Administration Of Ohio's Death Penalty, THE SUP. CT. OF OHIO \& OHIO JUD. SYS. 45 (Apr. 2014), http://www.sc.ohio.gov/Boards/deathPenalty/resources/dissentingReport.pdf.

44. Id. at 1 .

45. Id. 
The legislative postscript to this Ohio story should not come as much of a surprise: no doubt thanks to the prosecutors' dissenting report's "fear of too much capital justice," Ohio lawmakers have not seriously considered the vast majority of even the most moderate and modest recommendations to improve the state's modern administration of capital punishment. According to an accounting of the Task Force's work produced by the Ohio Criminal Sentencing Commission, three-quarters of the Task Force's proposals have been entirely ignored and have not prompted a single legislator even to propose a reform bill for implementation; only a handful of the other recommendations have been more than partially pursued or implemented ${ }^{46}$ Furthermore, to my knowledge, neither subsequent election campaigns nor lay advocacy about reform to Ohio criminal justice systems have had any discussion of capital punishment reform, suggesting that all the Sturm und Drang that surrounded the Task Force's work had little or no connection to the interests of the general public or the legislators elected to represent their interests.

\section{B. The Silver Lining of Capital Reform Efforts}

As stated at the outset of this Essay, my chief goals in this short space were to expose an enduring disconnect between lay interest and insider advocacy concerning death penalty reform, and to document my pessimistic view that even moderate and modest efforts to improve the modern administration of capital punishment may, more often than not, constitute something of a fool's errand. Nonetheless, ever the optimist, I will close by suggesting a few silver linings that might be drawn from this otherwise dark story in terms of enduring lessons and predictions for the future of the death penalty in the United States.

First, as suggested earlier, it might be far wiser for existing death penalty jurisdictions to simply try to end, their troubled modern capital punishment systems. But, politically and practically, it may prove much easier for capital abolition to emerge as a clear and appealing opinion for existing capital jurisdictions only after they make continued and concerted (failing) efforts to achieve "too much justice" in their death penalty systems. In nearly all states in which the death penalty has been

46. See The Sup. Ct. of OHIO \& OHIO Judicial Sys, Implementation Chart of SUMMARY OF RECOMMENDATIONS OF THE JOINT TASK FORCE TO REVIEW THE AdMINISTRATION OF OHIO'S DEATH PENALTy, (May 20, 2015), http://www.sc.ohio.gov/Boards/Sentencing/Materials/2015/May/jointTFRecommendations.pdf. 
recently abolished - states ranging from Connecticut to Illinois to Maryland to New Jersey - some sustained efforts to first improve a state's capital justice system preceded its legislative repeal. The significant difficulties and costs of seriously trying (and seriously failing) to improve capital punishment systems may need to be conspicuously displayed before legislators can feel fully comfortable concluding that ending the administration of the death penalty in a jurisdiction is a smarter move than continued failed efforts at mending it.

Moreover, even if failed efforts to fix the administration of the death penalty does not lead to its abolition, there may still be some unique and important spillover benefits for American criminal justice systems generally if capital jurisdictions continue to try to achieve "too much justice" in their death penalty systems. As insiders review soberly and realistically the wide array of criminal justice issues and problems pertaining to capital punishment, and especially because major problems identified in the administration of the death penalty-including wrongful convictions, racial and other disparities, poor quality and funding of defense counsel-plague the entire criminal justice system, reform efforts engendered by a desire to improve capital justice may facilitate needed work and attention focused toward remedying systemic problems that infest other parts of criminal justice systems. In modern America, concern for capital punishment's administration may ensure that our legal institutions do not get complacent about problems that pervade our criminal justice systems, and may even provide a critical means to engineer remedies to system-wide problems through broader legislative reform efforts. In other words, even if efforts to improve the modern administration of capital punishment may, more often than not, constitute something of a fool's errand, this foolishness still can foster an enhanced understanding of, and an enduring commitment to always taking on, the challenges of seeking "too much justice" throughout our criminal justice systems. For these reasons, though efforts to improve the administration of the death penalty may not produce short-term tangible results, the long-term benefits of these efforts perhaps should prompt us to applaud rather than fret when this kind of fool's errand gets underway. 